\title{
PENGARUH WAKTU PELEPASAN TOURNIQUET TERHADAP KADAR KALIUM PADA PENGAMBILAN DARAH VENA
}

\author{
The Effect of Time Tourniquet Release on Potassium Levels on Blood Venue Taking
}

\author{
Hadits Lissentiya Armal ${ }^{1}$, Heti Rais Khasanah², Leni Marlina ${ }^{3}$ \\ ${ }^{1,2,3}$ Analis Kesehatan Politeknik Kesehatan Kemenkes Bengkulu, \\ haditslissentiyaarmal@gmail.com/081288027809
}

\begin{abstract}
ABSTRAK
Tourniquet dapat menjadi masalah jika diikatkan terlalu lama dan dan terlalu erat pada saat pengambilan darah vena dapat mempengaruhi kadar kalium dan mengakibatkan kadar kalium tinggi palsu (pseudohiperkalemia). Penelitian ini bertujuan untuk mengetahui pengaruh waktu pelepasan Tourniquet terhadap kadar kalium pada pengambilan darah vena. Penelitian ini menggunakan metode Quasy Eksperimen dengan menggunakan rancangan Non-Equivalent Control group yang melibatkan dua grup dengan dua perlakuan yang berbeda. Variabel penelitian ini adalah waktu pelepasan tourniquet dan kadar kalium. Pengolahan data pada penelitian ini dilakukan secara univariat dan bivariat. Analisa data dalam penelitian ini juga menggunakan Uji T Independent untuk mengetahui pengaruh antar variabel. Hasil penelitian melalui analisa statistik didapatkan nilai rata-rata kadar kalium darah pada kelmopok pertama adalah 3,784 mEq/L dan kelompok kedua yakni 4,896 mEq/L. Dari hasil uji statistik diperoleh nilai $\mathrm{P}$ value $(0,000)<\alpha(0,05)$ yang berarti Ha diterima sehingga hasil dari penelitian ini adalah ada perbedaan rata-rata kadar kalium pada pelepasan tourniquet sesaat darah masuk dan pelepasan tourniquet setelah darah. Kesimpulan dari penelitian ini adalah waktu pelepasan tourniquet dapat mempengaruhi kadar kalium dan disarankan untuk bagi tenaga medis untuk melepaskan tourniquet sesaat darah masuk kedalam jarum spuit saat pengambilan darah vena untuk menghindari tingginya kadar kalium dalam serum.
\end{abstract}

Kata Kunci : Pelepasan tourniquet, Kadar Kalium, dan Pseudohiperkalemia

\section{ABSTRACT}

Tourniquet can be a problem if it is tied too long and too tightly when taking venous blood can affect potassium levels and result in high false potassium levels (pseudohiperkalemia). This study aims to determine the effect of Tourniquet release time on potassium levels in venous blood collection. This study uses the Quasy Experiment method using a Non-Equivalent Control group design involving two groups with two different treatments. The variables of this study were the time of tourniquet release and potassium levels. Data processing in this study was conducted in univariate and bivariate. Analysis of the data in this study also used the Independent T Test to determine the effect between variables.The results of the study through statistical analysis showed that the average blood potassium level in the first group was $3.784 \mathrm{mEq} / \mathrm{L}$ and the second group was $4.896 \mathrm{mEq} / \mathrm{L}$. From the results of statistical tests obtained a value of $P$ value $(0,000)<\alpha(0.05)$ which means Ha is accepted so that the results of this study are there are differences in the average potassium levels at the moment of release of tourniquet blood entering and releasing the tourniquet after blood. The conclusion of this study is that the release time of the tourniquet can affect potassium levels and it is recommended for medical personnel to release the tourniquet while the blood enters the syringe needle when taking venous blood to avoid high levels of potassium in the serum.

Keywords: Tourniquet Release, Potassium Levels, and Pseudohiperkalemia 


\section{PENDAHULUAN}

Suatu pemeriksaan yang dilakukan di laboratorium kesehatan agar mendapatkan hasil yang akurat harus dilakukan dengan baik dan benar pada semua tahap (pra analitik, analitik dan pasca analitik). Pengambilan sampel merupakan suatu kegiatan yang biasa dilakukan di laboratorium untuk suatu pemeriksaan dan pengambilan sampel ini termasuk ke dalam tahap pra analitik. Sampel merupakan bahan atau suspensi berupa cairan atau padatan yang selanjutnya akan diperiksa sesuai dengan parameter pemeriksaan yang dikehendaki. Pada pemeriksaan kimia klinik dilaboratorium menggunakan sampel urin atau serum. Salah satu contoh pemeriksaan kimia klinik yang menggunakan sampel serum adalah pemeriksaan elektrolit darah ${ }^{(1)}$

Pemeriksaan kadar kalium didalam tubuh berfungsi untuk mengetahui kadar kalium yang ada di dalam tubuh. Bila kadar kalium kurang dari 3,5 mEq/L disebut sebagai hipokalemia dan kadar kalium lebih dari $5,3 \mathrm{mEq} / \mathrm{L}$ disebut sebagai hiperkalemia. Kekurangan ion kalium dapat menyebabkan frekuensi denyut jantung melambat. Peningkatan kalium plasma $3-4 \mathrm{mEq} / \mathrm{L}$ dapat menyebabkan aritmia jantung, konsentrasi yang lebih tinggi lagi dapat menimbulkan henti jantung. Oleh Karena itu pemeriksaan elektrolit darah terutama kalium sangat perlu dilakukan untuk memantau kondisi atau keadaan keseimbangan asam basa dalam tubuh dan pemeriksaan kalium ini juga dilakukan sebelum melakukan tindakan operasi dengan tujuan yang sama yaitu untuk mengetahui keseimbangan elektrolit dalam tubuh pasien yang akan dioperasi ${ }^{(1)}$.
Pengambilan darah vena yang dilakukan dengan meggunakan tourniquet sebagai ikatan pembendung berfungsi untuk melihat vena yang berada dibawah jaringan kulit. Lama dan waktu pelepasan ikatan pembendung atau tourniquet ini berbeda pada masing-masing tekhnik plebothomy. Pada orang dewasa biasanya dipakai salah satu vena yaitu fossa cubiti dan pada bayi menggunakan vena jugularis superficialis atau di sinus sagitalis superior. Setelah ditegangkan kulit diatas vena dan tusuk kulit dengan jarum sampai masuk kedalam pembuluh darah vena dan kemudian lepaskan tourniquet sesaat darah masuk ke dalam spuit, lalu ditarik darah yang diperlukan ke dalam spuit dan lepaskan jarum spuit jika telah selesai pengambilan darah dengan mendapatkan sampel darah yang diperlukan ${ }^{(2)}$

Prosedur pengambilan darah vena dari penjelasan diatas terdiri dari dua cara, yakni pelepasan tourniquet dengan melepaskan tourniquet sesaat darah masuk kedalam jarum spuit dan tourniquet yang dilepas pada saat darah telah masuk spuit atau darah yang didapatkan telah mencapai jumlah yang diinginkan. Perlakuan dalam menentukan waktu pelepasan tourniquet yang diikatkan di lengan berpengaruh kepada hasil pemeriksaan kadar kalium dalam sampel serum darah tersebut. Yang mana jika tourniquet yang diikatkan tidak dilepaskan atau dikendorkan akan meningkatkan kadar kalium dalam serum $^{(3)(5)}$.

Dari hasil survei dilingkungan Analis Kesehatan Kota Bengkulu pengambilan darah vena dengan cara melepaskan tourniquet sesaat 
darah masuk kedalam jarum spuit. Namun sering juga terjadi kekeliruan yakni lupa untuk melepaskan atau mengendorkan tourniquet sesaat darah masuk dan baru dilepaskan setelah darah diambil.

\section{METODE PENELITIAN}

Jenis penelitian yang digunakan adalah Quasi Eksperiment (eksperimen semu), dengan cara melibatkan kelompok kontrol disamping kelompok eksperimental. Desain penelitian didasarkan pada studi keputusan dan masalah penelitian, yaitu untuk mengetahui beda kadar kalium dalam darah dengan pelepasan tourniquet sesaat darah masuk dan pelepasan tourniquet setelah darah masuk pada pengambilan darah vena menggunakan spuit pada pembuluh darah vena. Populasi penelitian ini adalah mahasiswa/mahasiswi Jurusan Analis Kesehatan Poltekkes Kemenkes Kota Bengkulu yang berjumlah 168 mahasiwa. Namun setelah melakukan observasi dengan beberapa kriteria yang telah ditentukan yang memenuhi kriteria ialah sebanyak 127 mahasiswa. Sampel pada penelitian ini adalah Dibutuhkan paling sedikit 25 mahasiwa dari sampel sebagai kelompok pertama dan 25 sampel sebagai kelompok kedua pada pengambilan sampel, dengan populasi melibatkan mahasiswa Analis Kesehatan sebanyak 127 orang. Pengolahan data pada penelitian ini dilakukan secara univariat dan bivariat. Analisa data dalam penelitian ini juga menggunakan Uji $\mathrm{T}$ Independent untuk mengetahui pengaruh antar variabel.

\section{HASIL}

Hasil pengukuran kadar kalium pada pengambilan darah vena. Distribusi kadar kalium menggunakan uji univariat. Analisis Univariat digunakan untuk melihat distribusi frekuensi kadar perbedaan kadar kalium pada pengambilan darah vena.

Tabel 1. Hasil Pengukuran Kadar Kalium
Pada Dua Perlakuan Dengan
Pelepasan Tourniquet Sesaat Darah
Masuk dan Pelepasan Tourniquet
Setelah Darah Masuk.

\begin{tabular}{lcccc}
\hline \multicolumn{1}{c}{$\begin{array}{c}\text { Perlakuan } \\
\text { Pelepasan } \\
\text { tourniquet }\end{array}$} & n & Mean & Median & Min-max \\
\hline $\begin{array}{l}\text { Sesaat Darah } \\
\text { Masuk }\end{array}$ & 25 & 3,784 & 3,800 & $3,5-4,1$ \\
$\begin{array}{l}\text { Setelah Darah } \\
\text { Masuk }\end{array}$ & 25 & 4,896 & 4,800 & $4,6-5,4$ \\
\hline
\end{tabular}

Sumber : Data Primer, 2018

Dari tabel 1 dapat diketahui hasil pengukuran kadar kalium pada kelompok pertama yakni pelepasan tourniquet sesaat darah masuk pada 25 sampel didapatkan ratarata $3,784 \mathrm{mEq} / \mathrm{L}$, median $3,800 \mathrm{mEq} / \mathrm{L}$, nilai kadar kalium terendah $3,5 \mathrm{mEq} / \mathrm{L}$ serta nilai kadar kalium tertinggi 4,1 mEq/L.

Pada kelompok kedua pelepasan tourniquet setelah darah masuk pada 25 sampel didapatkan rata-rata $4,896 \mathrm{mEq} / \mathrm{L}$, median 4,800 mEq/L, nilai kadar kalium terendah 4,6 $\mathrm{mEq} / \mathrm{L}$ serta nilai kadar kalium tertinggi 5,4 $\mathrm{mEq} / \mathrm{L}$.

Perbedaan kadar kalium pada kelompok pertama dan kedua, Untuk melihat apakah ada perbedaan kadar kalium pada pengambilan darah vena dengan menggunakan alat Analyzer (SE-1520) menggunakan Uji T- Independent. 
Tabel 2 Perbedaan Rata-Rata Kadar Kalium Pada Dua Perlakuan Dengan Pelepasan Tourniquet Sesaat Darah Masuk dan Pelepasan Tourniquet Setelah Darah Masuk Pada Mahasiswa/Mahasiswi Di Jurusan Analis Kesehatan Poltekkes Kemenkes Bengkulu.

\begin{tabular}{cccccc}
\hline Variabel & n & Mean & SD & p-value & SE \\
\hline Pelepasan tourniquet sesaat darah masuk & 25 & 3,784 & 0,1795 & 0,000 & 0,0359 \\
Pelepasan tourniquet setelah darah masuk & 25 & 4,896 & 0,2606 & & 0,0521 \\
\hline Sumbr
\end{tabular}

Sumber : Data Primer, 2018

Dari tabel diatas didapatkan rata-rata kadar kalium pada perlakuan pertama 3,784 $\mathrm{mEq} / \mathrm{L}$ dan rata-rata kadar kalium pada perlakuan kedua yakni 4,896 mEq/L. Dimana kadar kalium pada pelepasan tourniquet yang dilepas setelah darah masuk lebih tinggi dari pada tourniquet yang dilepas sesaat darah masuk. Hasil uji statistik diperoleh nilai $\mathrm{P}$ value $(0,000)<(0,05)$ yang artinya ada perbedaan yang rata-rata pelepasan tourniquet sesaat darah masuk dan pelepasan tourniquet setelah darah masuk pada mahasiswa / mahasiswi di Jurusan Analis Kesehatan Poltekkes kemenkes Bengkulu. Dimana kadar kalium pada pelepasan tourniquet yang dilepas setelah darah masuk lebih tinggi dari pada tourniquet yang dilepas sesaat darah masuk.

\section{PEMBAHASAN}

\section{Hasil Pengukuran Kadar Kalium pada pengambilan darah vena}

Dari hasil penelitian melalui analisa statistik didapatkan nilai rata-rata kadar kalium darah pada kelopok pertama adalah 3,784 $\mathrm{mEq} / \mathrm{L}$ sedangkan analisis data didapatkan nilai rata-rata kadar kalium pada perlakuan kedua yakni 4,896 mEq/L. Hal ini menunjukan ada perbedaan rata-rata kadar kalium pada dua perlakuan yang berbeda yakni ada perbedaan yang antara rata-rata pelepasan tourniquet sesaat darah masuk dan pelepasan tourniquet setelah darah masuk. Perbedaan rata-rata kadar kalium dari 3,784 $\mathrm{mEq} / \mathrm{L}$ menjadi 4,896 $\mathrm{mEq} / \mathrm{L}$ menunjukan adanya perbedaan dengan selisih 1,112 mEq/L.

\section{Perbedaan Kadar Kalium Pada Kelompok Pertama dan Kedua}

Didapatkan hasil normal pada kedua group dikarenakan peneliti memang ingin membandingkan kadar kalium dengan dua perlakuan yang berbeda saat pengambilan darah vena. Didapatkannya hasil normal ini dikarenakan para responden memang orang yang sehat dan yang telah memenuhi kriteria inklusi yang telah ditetapkan. Hal ini dapat menjadi masalah jika pasien yang akan memeriksakan kalium adalah orang yang dalam keadaan sakit namun kaliumnya masih dalam batas normal dan karena kesalahan praanalitik ini orang tersebut akan dinyatakan hiperkalemia yang mana kesalahan pra analitik ini akan meningkat sampai $2 \mathrm{mEq} / \mathrm{L}$.

Berdasarkan teori yang dikemukakan oleh Yawir (2012), tingginya kadar kalium dalam darah dapat disebabkan oleh hemolisis sampel tidak segera diperiksa atau kesalahan praanalitik yang lain yaitu tourniquet pada lengan atas tidak lepas pada saat pengambilan darah serta setelah penderita mengepalkan dan menggenggam tangannya berulangkali ini dapat terjadi peningkatan sampai $2 \mathrm{mEq} / \mathrm{L}^{(1)}$.

Pemasangan tourniquet dilakukan dengan pemasangan yang pas tidak perlu diikatkan erat-erat bahkan hanya cukup erat 
agar dapat memperlihatkan venanya saja. Serta jangan terlalu longgar yang menyebabkan tidak efektifnya sehingga vena tidak terlihat jelas dan tidak terlalu lama lebih dari 1 menit yang dapat menyebabkan hemokonsentrasi atau statis vena serta tinggi kadar kalium ${ }^{(4)}$.

Semakin lama membendung tourniquet dilengan akan mengakibatkan semakin tingginya kadar kalium dalam darah. Hal ini dikarenakan semakin banyak cairan intraseluler kalium yang bocor ke cairan ekstraseluler dan masuk kedalam serum. Yang dimungkinkan semakin tingginya kadar kalium dalam darah ${ }^{(6)}$.

Menurut Kowalak, et al (2010), pengambilan darah pada sampel harus dilakukan secepatnya setelah pemakaian tourniquet. Karena pelepasan tourniquet yang terlambat dapat menyebabkan penyempitan pembuluh darah yang akan mengakibatkan cairan intrasel (K) akan bocor kedalam serum, sehingga masuk kedalam cairan ekstrasel yang mana akan masuk kedalam serum, yang mengakibatkan pada saat dilakukan pengambilan darah vena serum yang didapatkan kadar kaliumnya tinggi. Namun ini tidak mecerminkan keadaan sebenarnya yang disebut kalium tinggi palsu atau pseudohiperkalemia $^{(6)}$.

Meningkatnya kadar kalium didalam serum dapat dikarenakan beberapa faktor yakni diantaranya. pengepalan tangan yang dilakukan berulang-ulang sebelum melakukan pengambilan darah vena, keterlambatan dalam pengambilan darah setelah pemakaian tourniquet atau hemolisis sampel yang berlebihan dapat meningkatkannya kadar kalium didalam serum, serta infus kalium yang berlebihan atau berlangsung cepat, terapi spironolakton atau kalium penisilin $\mathrm{G}$, dan toksisitas ginjal akibat pemberian amforesin B, metisilin, atau tetrasiklin yang dapat meningkatkan kadar kalium dalam serum ${ }^{(6)}$.

Kesalahan pra analitik terkadang dapat juga mempengaruhi hasil pemeriksaan yang merupakan tahap awal yang biasa dilakukan di laboratorium sehingga tidak tepatnya diagnosa dokter ketika mendapatkan hasil pemeriksaan laboratorium terhadap pasien dengan memberikan obat yang tidak sesuai dengan penyakit pasien. Maka dilakukan setiap tahap pemeriksaan dengan baik dan benar dri tahap (pra analitik, analitik serta pasca analitik).

Ada beberapa kelemahan dari penelitan ini yakni pertama pengambilan sampel tidak dilakukan pada sampel respondent yang sama, ditakutkan karena pada sampel respondent yang berbeda seseorang itu memang memiliki kadar kalium yang tinggi. Hendaknya dilakukan dengan orang yang sama agar dapat dipastikan bahwa ada pengaruh dari lamanya pelepasan tourniquet saat pengambilan darah vena.

\section{KESIMPULAN DAN SARAN}

Waktu pelepasan tourniquet dapat mempengaruhi kadar kalium dan disarankan untuk bagi tenaga medis untuk melepaskan tourniquet sesaat darah masuk kedalam jarum spuit saat pengambilan darah vena untuk menghindari tingginya kadar kalium dalam serum.

\section{DAFTAR PUSTAKA}

1. Yaswir R, Ferawati I. T Tinjauan Pustaka 
Fisiologi dan Gangguan Keseimbangan Natrium , Kalium dan Klorida serta Pemeriksaan Laboratorium. 2012;1(2):805.

2. Gandasoebrata,1999.Penuntun Laboratorium Klinik. Jakarta. Dian rakyat

3. Darmono. 2009. Penggunaan tourniquet dalam kehidupan dan dunia kesehatan http://www.ncbi.nlm.nih.gov/pubmed/1942 6141 diakses pada 13 Januari 2014

4. Muhtadir,Indra. 2013. Tourniquet. http://indramuhtadi.weebly.com/7/post/201 3/03/tourniquet.html diakses pada 6 januari 2013

5. Syamsi, Yunus. 2009.Rotating Tourniquet. http://wwwentersearch.blogspot.com/2009/ 06/rotating-tourniquet-j-niquetpengertian.html diakses pada 6 januari 2014

6. Kowalak, Jeniffer. 2010. Uji Diagnostik Edisi 3. Jakarta : Buku Kedokteran. EGC. 